\title{
What DNA can't tell: Scientific and ethical problems in using genetic tests to determine the nationality of migrants
}

\author{
Sarah Abel, Department of Anthropology, University of Iceland
}

Last July, there emerged several news reports that the Canada Border Services Agency (CBSA) is using direct-to-consumer (DTC) genetic ancestry testing services to determine the nationality of detained migrants.

Reports by Vice and the Toronto Star, for instance, described the case of Franklin Godwin, a former refugee granted permanent resident status in Canada in 1996 (Khandaker 2018; Keung 2018). After being convicted of criminal charges two years later, Canadian migration officials twice attempted to deport Godwin to his affirmed birth nation of Liberia. Both times, Liberian border officials denied him entry, claiming in 2003 that his travel documents were falsified, and then affirming in 2005 that he was not a Liberian national.

The CBSA has since begun to gather evidence that Godwin has been lying about his nationality. They now argue that he is Nigerian, based on his association with a Nigerian drug smuggling ring and his past attempts to travel to Nigeria. They have also taken the step of commissioning 'scientific' tests to support this theory. For instance, a Swedish firm, Sprakab, was contracted to perform a linguistic analysis on a 24-minute clip of Godwin's speech; the results concluded that he was more likely Nigerian than Liberian.

In a detention hearing earlier this year, the CBSA revealed that they had also taken a DNA sample from Godwin, which they sent to two commercial DNA ancestry-testing companies, FamilyTreeDNA and AncestryDNA. Using relative-matching tools, the CBSA subsequently contacted and interviewed two individuals who were genetically matched to Godwin - both British residents of Nigerian descent. A spokesperson for the Agency explained: 'DNA testing assists the CBSA in determining identity by providing indicators of nationality thereby enabling us to focus further lines of investigation on particular countries. The CBSA obtains consent from the clients before submitting their information to DNA websites' (Davidson 2018).

The use of DNA testing by migration officials is not a new phenomenon. For many years, genetic analysis has been recognized in a number of countries as a source of evidence for family reunification claims (Heinemann and Lemke 2012, 811). Nor is this the first case of DNA ancestry tests being employed to determine migrants' nationality: the UK Border Agency (UKBA) trialled and later discontinued the use of these technologies as part of their Human Provenance Pilot Project (HPPP) in 2009-10 (Tutton, Hauskeller, and Sturdy 2014). However, these are the first reports of commercial DNA ancestry testing databases being used in such inquiries.

These practices are a clear cause for concern. Not only do they imply a misunderstanding of the scope of genetics to shed light on legal and political issues such as nationality claims, but they also flag up complex ethical problems. What assumptions are being made here regarding the relationship between DNA, ancestry and nationality, and are they justified? Can detained migrants refuse DNA testing, or limit how their samples are used? How do these developments impinge upon other customers of DNA ancestry websites, and how far can companies control misuses of their services? 


\section{Scientific flaws: can DNA ancestry testing determine nationality?}

To answer this question, we need to first examine the relationship between nationality and ancestry. Nationality is defined as a legal and political concept that expresses an individual's membership of a nation state (Weis 1979, 3). Individuals usually acquire their nationality at birth, although it can also be changed later in life, e.g. through marriage or naturalization. Globally, there are two main principles used by states to accord nationality at birth: by descent (jus sanguinis), i.e. usually by having one or more parent or grandparent of that nationality; or by birthright (jus soli), i.e. being born in the state's territory. Most nations employ a combination of these principles: for instance, Liberian law accords nationality to anyone born in Liberia 'who is a Negro, or of Negro descent', or anyone born outside the country whose father is Liberian. The Nigerian state, on the other hand, gives nationality to anyone born in Nigeria since the country's independence (provided one or more of their parents or grandparents were born in Nigeria), and to anyone born outside of Nigeria to a Nigerian parent.

So, nationality can be related to ancestry - but not always, and only in a restricted sense. Most modern states have multi-ethnic populations, comprising people of different ancestries who have become nationals by various means. Crucially, nationality is not a natural phenomenon, but rather enshrined through bureaucratic and diplomatic procedures. As a result, a person can be left stateless due to conflicting nationality laws; meanwhile, states can also deprive individuals of their nationality - an act typically marked by the destruction of their personal papers.

Let us turn now to DNA ancestry testing. Companies such as FamilyTreeDNA and AncestryDNA specialize in providing customers with estimates about their ancestry, which are based on their genetic relatedness to selected reference populations from around the world, and to other customers within the company database. An obvious limitation to these services is that they deal solely with biological ancestry, which does not necessarily coincide with legal categories like nationality. As Subodh Bharati, Godwin's lawyer, stated: 'My DNA would say that I'm from India but I was born in Canada' (Kassam 2018).

As a matter of fact, it is unlikely that the results provided by these companies would even point clearly to a single country, as Bharati suggests. Genetic 'ethnicity' reports are generated by estimating the contributions of various ancestral populations to the customer's genome. Consequently, their results link the customer to numerous 'ethnic regions' or 'populations', rather than to one country or group. Moreover, the estimates provided by different companies can vary wildly. By way of example, I was born in Britain, as were three of my grandparents. According to reports by four leading companies, however, my 'British' genetic ancestry component is estimated, respectively, as 77.4 per cent, 53 per cent, 25.9 per cent, and nought per cent.

It is important to recognize that each company's DNA 'ethnicity' results are contingent on the contents of their reference population database, as well as how they categorize and label their results. For instance, Nigeria appears as a possible result in AncestryDNA's genetic 'ethnicity' analysis, whereas Liberia does not (fig. 1). FamilyTreeDNA, meanwhile, provides rather scant regional detail for Africa, dividing its results simply into 'West Africa', 'East Central Africa', and 'South Central Africa' (fig. 2). 
Nevertheless, news reports of Godwin's case describe the CBSA using genetic 'relativematching' tools, rather than 'ethnicity' estimates, in their investigations. These features work by connecting customers virtually via the detection of identical genomic segments, which are taken to be indicative of a recent common ancestry. For each customer, an algorithm produces a list of 'genetic relatives' ordered by their estimated degree of genealogical relatedness, based on their proportion of shared DNA (figs. 3 and 4). According to transcripts of Godwin's detention review hearing last February, CBSA agents used these tools to contact and interview two such 'relatives': one a 'second through a fourth cousin', the other a 'third through a fifth cousin' (Khandaker 2018).

From second-hand reports of the case, it is unclear what line of questioning the CBSA pursued with these individuals. One possibility is that they were hoping to locate relatives who knew Godwin personally, and could provide first-hand information on his nationality. However it seems unlikely that such distant relatives would be more reliable informants than friends or relatives who could be identified by other means. Another possibility is that they sought to demonstrate Godwin's nationality by showing he has Nigerian ancestors. Yet while having Nigerian ancestry is a criterion for being a national of that country, it by no means follows that Godwin himself is Nigerian.

As a side note, it should be stressed that DNA relative-matching tools do not necessarily offer concrete proof of relatedness, in the way the CBSA seems to assume. Due to the randomness of genomic patterns of inheritance, genealogical estimates - particularly among distant relatives - can be approximate, hence why companies present their results as a relationship range (e.g. 'second to fourth cousin'). Without additional contextual information, these algorithms are quite unable to distinguish between, say, a great-grandparent and a first cousin - both of whom theoretically share the same proportion of DNA with the testtaker. Thus, as any seasoned genealogist knows, the only way to verify the relationship between two genetically matched individuals (or, indeed, to ensure that a match is not a false positive) is through additional research. Even then, it should be recalled that kinship is not reducible to biology, making these tools powerless to shed light on family members who are not related 'by blood' (for instance, adoptees or 'in-laws').

So can DNA ancestry testing determine nationality? The answer is a categorical no.

\section{Ethical issues: justified use, consent and privacy}

And what of the ethical issues that this case raises? DNA testing in migration cases is meant to be a last resort, for use when other credible documentation is lacking. However, the uncritical acceptance of these methods as more trustworthy than migrants' words or papers often means that genetic data are used to trump other forms of evidence (Weiss 2011, 1). In this respect, the CBSA's of genetic ancestry tests on deportees raises similar concerns to other DNA identification procedures deployed by border and immigration agencies.

Since their invention in the mid-1980s, 'DNA fingerprinting' techniques have been lauded as a convenient and accurate way to verify the identities of immigrants. In one landmark family reunification case, the production of a DNA analysis helped convince the UK Home Office to drop charges against a Ghanaian teenager who was suspected of switching places with a cousin and falsifying a British passport to take up residency in the country (Jeffreys, Brookfield, and Semeonoff 1985; fig. 5). Commenting on the trial's positive outcome, the 
technique's inventor, Sir Alec Jeffreys, described it as a case of 'science acting for the individual against bureaucracy and the state' (Aronson 2005, 128).

Yet as these tools have been adopted into various countries' immigration procedures, bioethicists and migrants' representatives have suggested that they serve more frequently as a threat to civil liberties than as a source of empowerment for individuals and families. In particular, critics underline the 'dual standard' they create for immigrants vis-à-vis 'natural' citizens in terms of which relations are regarded as constitutive of a family unit, and what evidence is required to prove these relationships (Murdock 2008). The targeting of tests towards particular nationalities also raises concerns about racial discrimination. For instance, reports show that migration officials in Canada, among other countries, are trained to regard official documents from certain states (particularly in Africa, Asia and Latin America) as suspect, making migrants from those nations more likely to be subjected to DNA testing, and more vulnerable to data misuses (Granados Moreno, Ngueng Feze, and Joly 2017, 262; Joly et al. 2017, 395).

In their discussion of the UKBA's use of DNA ancestry tests to assess the origins of asylum seekers in 2009-10, Tutton et al. remarked: 'In a context where it is increasingly assumed that a high proportion of applicants do not tell the truth about their reasons for seeking admission to the country, the process is heavily weighted towards finding reasons to doubt the applicant's testimony and reject the application' (Tutton, Hauskeller, and Sturdy 2014, 742). There are clear parallels with the CBSA case, in which 'scientific' techniques such as DNA analyses and linguistic reports - whose reliability has also been strongly contested (Maniar 2014) - are being mounted as evidence against migrants' nationality claims. This is despite credible alternative explanations as to why deportees may be rejected by their home states - such as accounts of certain states that habitually refuse to cooperate in repatriating citizens, particularly those with criminal records (Khandaker 2018; Harris 2017). Faced with complex diplomatic issues, border agents may attempt to reach their deportation goals by following new 'leads' based on these reports, even when they contradict the claimant's account, earning them further detention time (Davidson 2018).

This leads on to the dubious ethics of obtaining consent for DNA testing from individuals threatened with indefinite detention - a tactic that Canadian immigration lawyer Peter Edelmann claims is used to gain migrants' cooperation (Davidson 2018). As one bioethicist has stated, 'Informed consent given under coercion is invalid' (Weiss 2011, 6) - and particularly so when refusal to give a DNA sample may be regarded as grounds for increased suspicion (Benjamin 2016). Furthermore, the CBSA appears to give donors little or no subsequent control over their samples - for example, Godwin was neither allowed to see his test results nor to contact his genetic matches (Khandaker 2018). Did agents allow him to decide whether or not his DNA could be used for research purposes by testing companies? Will his sample be destroyed, should he request it - a right often denied to detained migrants (Heinemann and Lemke 2012, 816)? Indeed, fulfilling this request may be beyond the scope of the CBSA, since commercial laboratories in the US (including those used by FamilyTreeDNA and AncestryDNA) are legally required to retain 'de-identified' genetic material for up to ten years for quality assurance and accreditation purposes.

Overall, accounts indicate that the CBSA's use of DNA testing in migration cases is subject to very little regulation or oversight, for instance in comparison to its sister agency, the Department of Citizenship and Immigration Canada (CIC), which has established a set of 
policy guidelines on this matter (Davidson 2018; Joly et al. 2017). For the CBSA, the appeal of using a commercial DNA testing service is clear: these companies offer cheap, quick sample processing, a readymade international database and easy-to-use genetic-matching tools. In comparison, transnational requests for DNA samples in irregular migration cases usually require bilateral cooperation with foreign police forces, and adhesion to international legal frameworks (McCartney, Wilson, and Williams 2011). Yet circumventing these protocols means potentially infringing the rights of other customers of these services, who have not consented for their DNA to be used in legal inquiries.

Both AncestryDNA and FamilyTreeDNA have stated they do not work directly with border agencies, and their priority is protecting the privacy of users (Khandaker 2018). Yet how realistic is this? Each company requires customers to sign terms and conditions confirming they have legal authority over the DNA being submitted - but this is almost impossible to verify. Both reserve the right to delete profiles that violate their terms of use, although it is unclear whether this has been done in Godwin's or other cases. Demonstrably, companies have little control over who gains access to their services, or for what purposes. Meanwhile, the limits of their privacy provisions seem to constitute enabling customers to opt out of their relative-matching services, a sacrifice that many will be unwilling to make.

\section{Towards more responsible norms and uses}

Recent news reports have shed light on a handful of cases like Godwin's, in which commercial DNA ancestry tests have been used as a tool for determining the nationality of individuals listed for deportation. And while the CBSA has admitted to these practices, it is unknown whether other state border agencies are also resorting to these techniques. Either way, these examples signal the need for clearer norms, as well as greater transparency and legal oversight, to prevent future misuses of these technologies by migration officials and other law enforcement agencies.

For example, it is concerning that impersonal 'scientific' analyses should be used to trump other sources of evidence about migrants' identities - and better training for officials about these technologies and the conditions that can complicate the identification of individuals' nationalities may help prevent such abuses. Above all, it should be understood that genetic ancestry technologies are not scientifically useful for providing 'indicators of nationality,' and are therefore not appropriate sources of evidence in investigations of this kind.

Meanwhile, migrants should be given clear rights to refuse testing and request the destruction of their DNA sample and data, without affecting the outcome of their investigation - an argument that has previously been put forward for family reunification cases (Benjamin 2016). Overall, shifting the onus away from blaming and coercing individuals, and towards understanding and solving diplomatic issues that can lead to deportation conflicts, may help prevent the needless and long-term detention of migrants.

Finally, it should be recognized that the use of commercial genetic testing databases in legal and criminal investigations can infringe the rights of other users, and should be prohibited. For their part, commercial DNA testing companies could improve their own ethical standards by clarifying the limitations of their ability to guarantee privacy to users, as well as creating explicit guidelines for what constitutes misuses of their services; enabling customers to 
easily recognize and report inappropriate practices; and establishing effective protocols to impede such activities.

The CBSA case is probably not one of a kind. It seems to be increasingly common for immigration officials in different countries to demand DNA tests from migrants, for reasons and uses that are not always clear or coherent. Even when the motives seem both transparent and worthy - as in the company 23andMe's recent pledge to provide DNA testing kits to help reunite Central American migrant families separated at the US border (Ho 2018; fig. 6) - it is important to scrutinise the possible risks and abuses this may incur. Can migrants be guaranteed that their genetic data will not be stored permanently by the state, used against them in court, or sold to third parties? Going forward, experts and policymakers should consider the appropriateness of collecting DNA for these purposes and, if DNA testing is implemented, what legal mechanisms can be put in place to safeguard the rights of vulnerable individuals, as well as regular users of commercial DNA testing services.

\section{Acknowledgements}

I would like to thank Gísli Pálsson, Hannes Schroeder, Elise Burton, Megan Ryburn, and the paper's anonymous reviewer for their insightful comments during the preparation of the manuscript. The article was produced as part of the CitiGen project, which has received generous funding from the European Union's Horizon 2020 research and innovation programme, under grant agreement No 649307.

\section{References}

Aronson, Jay D. 2005. DNA fingerprinting on trial: the dramatic early history of a new forensic technique. Endeavour 29 (3): 126-31.

Benjamin, Ruha. 2016. Informed refusal: toward a justice-based bioethics. Science, Technology, \& Human Values 41 (6): 967-90.

Davidson, Terry. 2018. Canada's use of DNA and ancestry sites in detainees' deportation cases problematic, lawyers say. The Lawyer's Daily, 16 August 2018, sec. Immigration. https://www.thelawyersdaily.ca/articles/7123.

Granados Moreno, Palmira, Ida Ngueng Feze, and Yann Joly. 2017. Does the end justify the means? A comparative study of the use of DNA testing in the context of family reunification. Journal of Law and the Biosciences 4 (2): 250-81.

Harris, Kathleen. 2017. 15,000 on Canada's reportation list, but some 'unco-operative' countries won't take their citizens back. CBC, 20 November 2017. https://www.cbc.ca/news/politics/deportation-uncooperative-countries-1.4405383.

Heinemann, Torsten, and Thomas Lemke. 2012. Suspect families: DNA kinship testing in German immigration policy. Sociology 47 (4): 810-26.

Ho, Catherine. 2018. 23andMe's DNA kit offer for reuniting migrant families raises privacy concerns. San Francisco Chronicle, 22 June 2018, sec. Business. https://www.sfchronicle.com/business/article/23andMe-s-DNA-kit-offer-for-reunitingmigrant-13018584.php.

Jeffreys, Alec J., John F. Y. Brookfield, and Robert Semeonoff. 1985. Positive identification of an immigration test-case using human DNA fingerprints. Nature 317 (6040): 81819.

Joly, Yann, Shahad Salman, Ida Ngueng Feze, Palmira Granados Moreno, Michèle StantonJean, Jacqueline Lacey, Micheline Labelle, et al. 2017. DNA testing for family 
reunification in Canada: points to consider. Journal of International Migration and Integration 18 (2): 391-404.

Kassam, Ashifa. 2018. Canada uses DNA and ancestry sites to check migrants' identity. The Guardian, 30 July 2018, sec. World.

https://www.theguardian.com/world/2018/jul/30/canada-uses-dna-and-ancestry-sitesto-check-migrants-identity.

Keung, Nicholas. 2018. Border agents using DNA databases like familytree.com and ancestry.com to ID detainees, track relatives. The Star, 6 August 2018. https://www.thestar.com/news/gta/2018/08/06/border-agents-using-dna-databaseslike-familytreecom-and-ancestrycom-to-id-detainees-track-relatives.html.

Khandaker, Tamara. 2018. Canada is using ancestry DNA websites to help it deport people. Vice, 26 July 2018. https://news.vice.com/en_ca/article/wjkxmy/canada-is-usingancestry-dna-websites-to-help-it-deport-people.

Maniar, Aisha. 2014. Language testing of asylum claimants: a flawed approach. Institute of Race Relations (blog). 7 August 2014. http://www.irr.org.uk/news/language-testingof-asylum-claimants-a-flawed-approach/.

McCartney, Carole I., Tim J. Wilson, and Robin Williams. 2011. Transnational exchange of forensic DNA: viability, legitimacy, and acceptability. European Journal on Criminal Policy and Research 17 (4): 305-22.

Murdock, Tera Rica. 2008. Whose child is this? Genetic analysis and family reunification immigration in France. Vanderbilt Journal of Transnational Law 41 (5): 1503-34.

Tutton, Richard, Christine Hauskeller, and Steve Sturdy. 2014. Suspect technologies: forensic testing of asylum seekers at the UK border. Ethnic and Racial Studies 37 (5): 738-52.

Weis, Paul. 1979. Nationality and statelessness in international law. Alphen aan den Rijn: Sijthoff \& Noordhoff.

Weiss, Martin G. 2011. Strange DNA: the rise of DNA analysis for family reunification and its ethical implications. Genomics, Society and Policy 7 (1): 1. 